\title{
The Effect Of Brand Ambasador and Prices on The Purchase Decision Of Android Hand Phone Through Interest In Buying Consumers In Medan City
}

\author{
Indawati Lestari ${ }^{1}$, Martin ${ }^{2}$, Marihot Manullang ${ }^{3}$, Ribka Sari Butar-Butar ${ }^{4}$, Zulia Rifda Daulay ${ }^{5}$ \\ ${ }^{1}$ Universitas Medan Area, Indonesia \\ 2,5 Politeknik Unggul LP3M, Indonesia \\ ${ }^{3}$ Universitas Pembinaan Masyarakat Indonesia \\ ${ }^{4}$ Universitas Prima Indonesia \\ *Corresponding Author: \\ Email: indahtaca@gmail.com
}

\begin{abstract}
.
The main purpose of this study is to determine the effect of brand ambassadors and prices on purchasing decisions for Android phones through consumer buying interest. The approach in this study is associative with the data analysis used is path analysis. The population and sample in this study were 147 respondents who were selected by accidental sampling. The results showed that (1) brand ambassadors had a positive and significant effect on buying interest, (2) price had a negative effect on buying interest, (3) brand ambassadors had a positive and significant effect on purchasing decisions, (4) price had a negative effect on purchasing decisions, (5) brand ambassador has a positive and significant effect on purchasing decisions through buying interest, (6) price has a negative effect on purchasing decisions through buying interest.
\end{abstract}

Keywords: Ambassador, Price, Interest, Purchase Decision

\section{INTRODUCTION}

Along with the times and increasing human mobility, the development of information and communication technology has become a field that is developing very rapidly. One of them is a mobile phone or cell phone. If in the past it was only used to make calls or send short messages, now this mobile technology can perform even more tasks. Today's cell phones can send and receive e-mails, play music and videos, guide trips with GPS (Global Positioning System), even browse the internet and also do banking business transactions. This type of mobile phone is often called a smart phone. In other words, a smartphone is a mobile phone that has a high level of capability, sometimes with functions that resemble a computer. There are many types of smartphones used by the public, one of which is Android.

Android is a Linux-based operating system designed for touch-screen mobile devices such as smartphones and tablet computers. Android was originally developed by Android, Inc., with financial support from Google, which later purchased it in 2005. Along with its development, Android has many competitors, one of which is Android. One of them is iOS. The iOS operating system is in great demand by the upper middle class and even people are willing to spend tens of millions just to buy products from iOS, so in this case it is necessary to develop a strategy from Android so that it does not compete with other products. The purchase decision is the stage of the decision process in which the consumer actually purchases the product [1]. The buying decision-making process consists of five stages: need recognition, information search, evaluation of alternatives, purchase decision, and post-purchase behavior. Furthermore, there are several purchasing decision approaches which include a stimulus-response approach, a humanistic approach, a combination of stimulus-response and humanistic approaches, and persuasive communication approaches. [2].

Consumer buying interest reflects the desire and desire of consumers to buy a product [3]. Then buying interest can also be interpreted as how likely consumers are to buy a brand and service or how likely 
consumers are to move from one brand to another [2]. If the benefits are greater than the sacrifice to get it, the impulse to buy is higher.

There are many factors that can improve consumer purchasing decisions, some of which are brand ambassadors and the price offered is of course mediated by consumer buying interest. Brand ambassadors play an important role in influencing purchasing decisions [4]. Brand ambassador as a promotion in marketing their products, of course consumers will be more interested in the products used by public figures that can influence their purchasing decisions for a product, here is the definition of a brand ambassador. someone who presents the best portrait or image of a product. This person is usually from among celebrities or other popular people [5]. The use of brand ambassadors is carried out by companies to influence or invite consumers. It is intended that consumers are interested in using the product, especially because the selection of brand ambassadors is usually based on imaging through a well-known celebrity. Based on some of the definitions above, it can be interpreted that a brand ambassador is an effort made by a company to influence or invite consumers by using celebrities as icons to present the best image of a product, so that consumers are interested in using the product.

Price also has a significant influence on purchasing decisions [6]. Price can be interpreted as the amount of money charged for an item or service or the sum of the value of money exchanged by consumers for the benefits of owning or using the product or service. [2]. Pricing policy strategies are decisions about prices set by management. The objectives of the firm's pricing policy strategy which include pricing to maximize profits), pricing for market share and launching market prices [7].

\section{METHODS}

This research uses associative quantitative research. The population in this study were all consumers of android cellphones in the city of Medan. Sampling technique using accidental sampling. The number of samples in this study were 147 customers. Data analysis using path analysis

\section{RESULT AND DISCUSSION}

Tabel 1. Coefficient of Determination Test Results $\left(\mathrm{R}^{2}\right)$ Sub 1Model Summary ${ }^{\mathrm{b}}$

\begin{tabular}{|l|l|l|l|l|}
\hline Model & $\mathrm{R}$ & R Square & $\begin{array}{l}\text { Adjusted R } \\
\text { Square }\end{array}$ & $\begin{array}{l}\text { Std. Error of } \\
\text { the Estimate }\end{array}$ \\
\hline 1 &, $772^{\mathrm{a}}$ &, 521 &, 515 & 2,56997 \\
\hline
\end{tabular}

a. Predictors : (Constant), price, brand ambassador

b. Dependent Variable : Buying interest

From Table 1 it is known that the Adjusted $\mathrm{R}$ Square value is 0.515 or $51.5 \%$. This value gives an understanding that the brand ambassador (X1) and price (X2) have an effect on buying interest (Z) by 51.5\%.

Tabel 2. Hasil Simultaneous Test (Uji F) Sub 1ANOVA ${ }^{a}$

\begin{tabular}{|c|c|c|c|c|c|}
\hline Model & $\begin{array}{c}\text { Sum of } \\
\text { Squares }\end{array}$ & Df & $\begin{array}{c}\text { Mean } \\
\text { Square }\end{array}$ & F & Sig \\
\hline Regression & 1035,342 & 2 & 517,671 & 78,379 &, $000^{\mathrm{b}}$ \\
Residual & 951,080 & 144 & 6,605 & & \\
Total & 1986,422 & 146 & & & \\
\hline
\end{tabular}

a. Dependen Variable : buying interest

b. Predictors : (Constant), price, brand ambassador

Based on Table 2, it is found that the Fcount value is 78.379 with a significant level of 0.000 which is smaller than an alpha of $0.05(5 \%)$. The calculated F produced is 78.379 , which is greater than the Ftable, which is 2.67 . Thus, simultaneously brand ambassador (X1) and price (X2) have a positive and significant effect on employee satisfaction (Z).

Tabel 3. Partial Effect Significance Test Sub 1

\begin{tabular}{|c|c|c|c|c|}
\hline Model & $\begin{array}{c}\text { Unstandardized } \\
\text { Coefficients }\end{array}$ & $\begin{array}{c}\text { Standardized } \\
\text { Coefficients }\end{array}$ & $\mathrm{T}$ & Sig \\
\hline
\end{tabular}




\begin{tabular}{|c|c|c|c|c|c|}
\hline & B & Std. Error & Beta & & \\
\hline 1 & 25,978 & 2,352 & & 11,045 &, 000 \\
(Constant) &, 191 &, 037 &, 334 & 5,117 &, 000 \\
Brand &,- 427 &, 055 &,- 503 & $-7,714$ &, 000 \\
ambassador & & & & & \\
Price & & & & & \\
\hline
\end{tabular}

Dependent Variabel : Buying interest

Based on Table 3, the following regression equation is obtained: $\mathrm{Y}=0.191 \mathrm{X} 1+-427 \mathrm{X} 2$

Tabel 4.Hasil Coefficient of Determination Test $\left(\mathrm{R}^{2}\right)$ Sub 2 Model Summary ${ }^{\mathrm{b}}$

\begin{tabular}{|l|l|l|l|l|}
\hline Model & $\mathrm{R}$ & R Square & $\begin{array}{l}\text { Adjusted R } \\
\text { Square }\end{array}$ & $\begin{array}{l}\text { Std. Error of } \\
\text { the Estimate }\end{array}$ \\
\hline 1 &, $776^{\mathrm{a}}$ &, 602 &, 594 & 2,32153 \\
\hline
\end{tabular}

a. Predictors : (Constant), buying interest, price, brand ambassador

b. Dependent Variable : buying decision

From Table 4 it is known that the Adjusted R Square value is 0.594 or $59.4 \%$. This value gives an understanding that the brand ambassador (X1), price (X2), and buying interest (Z) affect purchasing decisions (Y) by $59.4 \%$.

Tabel 5. Simultaneous Test Results (Uji F) Sub 2 ANOVA $^{\mathrm{a}}$

\begin{tabular}{|c|c|l|c|c|c|}
\hline Model & $\begin{array}{c}\text { Sum of } \\
\text { Squares }\end{array}$ & \multicolumn{1}{|c|}{ Df } & $\begin{array}{c}\text { Mean } \\
\text { Square }\end{array}$ & F & Sig \\
\hline Regression & 1167,191 & 3 & 389,064 & 71,189 &, $000^{\mathrm{b}}$ \\
Residual & 770,701 & 143 & 5,390 & & \\
Total & 1937,891 & 146 & & & \\
\hline
\end{tabular}

a. Dependen Variable : buying interest

b. Predictors : (Constant), buying interest, price, brand ambassador

Based on Table 5, it is found that the Fcount value is 72.189 with a significant level of 0.000 which is smaller than an alpha of $0.05(5 \%)$. The calculated F produced is 72.189 , which is greater than Ftable, which is 2.67. Thus, simultaneously brand ambassador (X1), price (X2) and buying interest (Z) have a positive and significant effect on purchasing decisions $(\mathrm{Y})$.

Tabel 6 Partial Effect Significance Test Sub 2 Coefficients ${ }^{\text {a }}$

\begin{tabular}{|c|c|c|c|c|c|}
\hline Model & \multicolumn{2}{|c|}{$\begin{array}{c}\text { Unstandardized } \\
\text { Coefficients }\end{array}$} & $\begin{array}{c}\text { Standardized } \\
\text { Coefficients }\end{array}$ & \multirow{2}{*}{ Sig } \\
\cline { 2 - 4 } & $\mathrm{B}$ & Std. Error & Beta & $\mathrm{t}$ &, 003 \\
\hline 1 & 8,855 & 2,888 & & 3,066 &, 000 \\
(Constant) &, 202 &, 037 &, 357 & 5,502 &, 004 \\
Brand &,- 172 &, 059 &,- 206 & $-2,901$ &, 000 \\
ambassador &, 349 &, 075 &, 354 & 4,639 & \\
Price & & & & & \\
Buying & & & & & \\
interest & & & & & \\
\hline
\end{tabular}

Dependent Variabel : buying decision

Based on Table 6 , the following regression equation is obtained $\mathrm{Y}=0.202 \mathrm{X} 1+-0.172 \mathrm{X} 2+0.349 \mathrm{Z}$

The Influence of Brand Ambassadors on Interest in Buying Android Phones in Medan City

Brand ambassadors are individuals who disseminate information about the products of a company [2]. The use of brand ambassadors is carried out by companies to influence or invite consumers to use products, the use of brand ambassadors usually uses well-known celebrities. Seeing the conditions and the role of technology in today's business world, business people take advantage of all the opportunities that exist to be able to communicate the products and brands sold in this case the brand ambassador is able to increase consumer buying interest. The use of brand ambassadors is currently one of the mainstay marketing 
strategies for companies to continue to grow and compete. Usually companies choose celebrities, expertise in their fields to influence consumers' desire to want to use the products offered. This is in line with research conducted by [8][9] which states that brand ambassadors significantly affect buying interest.

\section{The Influence of Price on Interest in Buying Android Phones in Medan City}

Price is generally the main thing that prospective consumers pay attention to when they want to buy a product. High or low prices will determine someone in buying an item. Through the price, a person can decide whether the product will be owned and consumed or vice versa. Price is the amount of money that is exchanged for a product or service, furthermore, price is the sum of all the values that consumers exchange for the number of benefits by having or using an item and service that can affect buying interest. Perception of price has a strong influence on consumers in making choices, price perception is the tendency of consumers to use price in assessing the suitability of product benefits.

The assessment of the price on a product benefit is said to be expensive, cheap or moderate from each individual is not the same, because it depends on individual perceptions that are motivated by the environment and individual conditions themselves. This buying interest arises when a consumer sees a product and service offered, both in terms of appearance, packaging, and advantages and how much money will be spent to get the product. This is in line with research conducted by [10]-[13] that the price significantly affects buying interest.

\section{The Influence of Brand Ambassadors on Android Phone Purchase Decisions in Medan City}

In human life, some decisions are influenced by idols or trendsetters. In the world of marketing, this trendsetter is often used to become a brand ambassador. A brand ambassador is someone who has a passion for the brand and can influence or invite consumers to buy or use a product. For a company, the use of brand ambassadors aims to influence consumers in buying products. Companies must be able to know consumer demand so that companies can choose the right brand ambassador for their products. The right brand ambassador serves to influence and become a trendsetter for the products the company sells. The existence of a brand ambassador can increase consumer purchases with the influence of the brand ambassador. This is in line with research conducted by [13]-[15] that brand ambassadors significantly influence purchasing decisions.

\section{The Influence of Price on the Decision to Purchase Android Phones in Medan City}

Price is one of the factors that influence a person's purchase decision. Consumers will buy a product that suits their abilities. Companies must consider this, because in competition the prices offered by competitors can be lower prices with the same quality and can be at higher prices. For this reason, the role of price greatly affects the level of success of a company in selling its products. Price has two main roles in the decision-making process of buyers, namely: (1) The role of price allocation, namely the price function in helping buyers to decide how to obtain the highest expected benefit or utility based on their purchasing power. The existence of prices can help buyers to decide how to allocate their purchasing power to various types of goods and services. The buyer compares the prices of various available alternatives, then decides on the desired allocation of funds; (2) The role of price information, namely the function of price in 'educating' consumers about product factors, such as quality. This is especially useful in situations where buyers have difficulty assessing the product's factors or benefits. This is in line with research conducted by [16][17] that price significantly influences purchasing decisions.

\section{The Influence of Buying Interest on Purchase Decisions for Android Phones in Medan City}

Buying interest can also be interpreted as a tangible form of thought from the reflection of the buyer's plan to buy several units in a certain number of several brands that are available within a certain time period. In the buying process, consumer buying interest is closely related to the motives they have to use or buy certain products. Buying interest is obtained from a learning process and a thought process that forms a perception. This buying interest creates a motivation that continues to be recorded in his mind and becomes a very strong desire which in the end when a consumer has to fulfill his needs will create a purchase decision. This is in line with research conducted by [4], [18] that buying interest significantly influences purchasing decisions. 
The Influence of Brand Ambassadors on Purchase Decisions Through Interest in Buying Android Phones in Medan City

Brand ambassadors play a very important role in helping smooth marketing activities both locally and globally. Brand ambassadors will help create a stronger emotional connection between a company's brand and consumers so that it will indirectly build buying interest so that it will have an impact on purchasing decisions. The company chooses Brand Ambassadors from among popular people so that they can be a booster in their sales promotions. In addition, Brand Ambassadors can also help bring consumers closer to a product, in order to attract more consumer interest in a product being offered.

Brand Ambassador is someone who presents the best portrait or image of a product. This person is usually from among celebrities or other popular people. Brand Ambassadors or commonly referred to as product ambassadors are communicators who have an important role in conveying messages about a product that will be offered to consumers. The main purpose of using celebrities as Brand Ambassadors is to influence consumers' buying interest through celebrity popularity and fame which is one of the strategies often used by companies in marketing their products. This is in line with research conducted by [4], [18]-[22].

\section{The Influence of Price on Purchase Decisions Through Interest in Buying Android Phones in Medan City}

Price is a number of values charged to a product by looking at the usefulness of the product that is needed by consumers. The appropriate price will affect buying interest, namely the existence of an impulse that arises in a buyer to buy a product to meet his needs. Therefore, repurchase tends to be caused by past behavior with subjective norm attitudes. The subjective attitude itself is influenced by beliefs in the consequences of behavior. Thus, repeat purchases tend to be due to past behaviors that directly affect the intention to repurchase in the future. Therefore, the individual's interest will arise a desire that finally convinces that the item can meet his needs so that the individual will want to have the item and buy it at a predetermined price. This is in line with research conducted by [23], [24].

\section{CONCLUSION}

Brand ambassador has a positive and significant effect on buying interest. It can be stated that when the brand ambassador is getting better or improved, it will increase the frozen interest of consumers.Price has a negative and significant effect on buying interest. So that when prices increase, this will have an impact on decreasing consumer buying interest.Brand ambassador has a positive and significant effect on purchasing decisions.

This means that increasing brand ambassadors will be able to improve consumer purchasing decisions.Price has a negative and significant effect on purchasing decisions. These results indicate that when the price of a product is increased it will have an impact on decreasing consumer purchasing decisions. Purchase intention has a positive and significant effect on purchasing decisions. These results indicate that when buying interest is getting better, it will encourage consumers to make purchasing decisions in the future.Price has a negative and significant effect on purchasing decisions through buying interest. These results indicate that when the price of the product is increased, it will affect the decrease in consumer buying interest and have an impact on the tendency to decrease consumer purchasing decisions.

Brand ambassador has a positive and significant effect on purchasing decisions through buying interest. This means that buying interest has a role in mediating brand ambassadors on purchasing decisions. Increasing this brand ambassador will affect buying interest and have an impact on increasing consumer purchasing decisions.

\section{ACKNOWLEDGMENTS}

The author expresses his deepest gratitude for the cooperation between the other members. The author hopes that this collaborative activity will be well established in the future.

\section{REFERENCES}

[1] P. Kotler, Manajemen Pemasaran, 13th ed. Jakarta: Prehallindo, 2009. 
[2] P. K. K. L. Keller, Manajemen Pemasaran Edisi 12. Jakarta: Erlangga, 2012.

[3] F. Tjiptono, Pemasan Jasa-Prinsip, Penerapan, dan Penelitian. Yogyakarta, 2014.

[4] V. L. F. C. T. C. H. S. J. C. P. L. M. Jaacks, "Food Purchasing Decisions Of Malawian Mothers With Young Children In Households Experiencing The Nutrition Transition,” Appetite, vol. 156, no. May 2020, pp. 1-8, 2021.

[5] A. W. Soehadi, A Value Creation Approach. Jakarta: Prasetia Mulya, 2012.

[6] N. Martin, "The Influence Of The Price Cuts And The Atmosphere Of Thte Campus Of Impulse Buying Studi In The Politeknik Unggul LP3M," in ICOES, 2018, vol. 1, pp. 1-7.

[7] D. Saladin, Intisari Pemasaran dan Unsur-unsur Pemasaran, Cetakan Keempat. Jakarta: Linda Karya, 2011.

[8] M. F. I. R. N. Rubiyanti, "Pengaruh Brand Ambassador Terhadap Minat Beli Tiket.Com Di Jawa Barat," $e$ Proceeding Manag., vol. 8, no. 1, pp. 164-170, 2021.

[9] A. S. M. A. Wardhana, "Pengaruh Brand Ambassador Terhadap Minat Beli Konsumen Bandung Kunafe Cake," e-Proceeding Manag., vol. 5, no. 2, pp. 2577-2583, 2018.

[10] C. H. Yen and H. Hsi-Peng, "Factors influencing online auction repurchase intention," Internet Res., vol. 18, no. 1, pp. 7-25, 2008.

[11] A. P. Graciola, D. De Toni, V. Z. de Lima, and G. S. Milan, "Does price sensitivity and price level influence store price image and repurchase intention in retail markets?," J. Retail. Consum. Serv., vol. 44, no. November 2017, pp. 201-213, 2018.

[12] L. J. Liang, H. C. Choi, and M. Joppe, "Understanding repurchase intention of Airbnb consumers: perceived authenticity, electronic word-of-mouth, and price sensitivity," J. Travel Tour. Mark., vol. 35, no. 1, pp. 73-89, 2018.

[13] Y. He, L. K. Chan, and S. K. Tse, "From consumer satisfaction to repurchase intention: The role of price tolerance in a competitive service market," Total Qual. Manag. Bus. Excell., vol. 19, no. 9, pp. 949-961, 2008.

[14] D. Apriliani, I. G. Arimbawa, and A. Wulandari, "How Youtube Beauty Vlogger Review, Self Congruity and Price Perception Influence Impulse Buying and the Impact On Repurchase Intention (Case Study at Teenager Users of Emina Cosmetics In Surabaya)," Quant. Econ. Manag. Stud., vol. 1, no. 1, 2020.

[15] V. Swaen and R. C. Chumpitaz, "Impact of Corporate Social Responsibility on Consumer Trust," Rech. Appl. en Mark. (English Ed., vol. 23, no. 4, pp. 7-34, 2008.

[16] N. S. A. M. Z. F. Wasiman, "Do Purchase or Do no Purchase ? Customer Purchasing Decisions By Using OVO Application," in Proceedings of the 2nd Annual Conference on Blended Learning, Educational Technology and Innovation (ACBLETI 2020) Do, 2021, vol. 560, no. Acbleti 2020, pp. 386-389.

[17] Nasib, “Optimalisasi Personal Selling, Lokasi Dan Harga Dalam Meningkatkan Keputusan Mengikuti Program Kepemilikan Rumah KPR Tipe 36,” J. Mantik Penusa, vol. 3, no. 1, pp. 14-20, 2019.

[18] G. W. Zheng, A. B. Siddik, M. Masukujjaman, S. S. Alam, and A. Akter, "Perceived environmental responsibilities and green buying behavior: The mediating effect of attitude," Sustain., vol. 13, no. 1, pp. 1-27, 2021.

[19] E. L. O’Connor, L. Sims, and K. M. White, “Ethical food choices: Examining people's Fair Trade purchasing decisions," Food Qual. Prefer., vol. 60, no. April, pp. 105-112, 2017.

[20] E. Isabelita, E. Limpong, P. Kindangen, and W. J. F. A. Tumbuan, “E . I . E . Limpong ., P . Kindangen ., W . J . F . A . Tumbuan The Impact Of Consumer Review On Purchase Intention Of Internet / Telephone Service Provider In Manado Dampak Dari Ulasan Konsumen Terhadap Minat Beli Penyedia Layanan Internet / Telepon Di M," vol. 9, no. 1, pp. 52-60.

[21] S. Sharma, S. Singh, F. Kujur, and G. Das, "Social Media Activities and its Influence on Customer-Brand Relationship: An Empirical Study of Apparel Retailers' Activity in India," J. Theor. Appl. Electron. Commer. Res., vol. 16, no. 4, pp. 602-617, 2020.

[22] Z. D. A. GAziz, M. K. Omar, and S. Ariffin, "The Effects of Celebrity Endorsements towards Purchase Intention among Malaysian Millennials," Reli. Rev. Ciencias Soc. y Humanidades, vol. 4, no. 7, pp. 198-206, 2019.

[23] H. Wen and X. Y. Leung, "Virtual wine tours and wine tasting: The influence of offline and online embodiment integration on wine purchase decisions," Tour. Manag., vol. 83, no. May 2020, p. 104250, 2021.

[24] N. W. Masri, A. Ruangkanjanases, and S. C. Chen, "The effects of product monetary value, product evaluation cost, and customer enjoyment on customer intention to purchase and reuse vendors: Institutional trust-based mechanisms," Sustain., vol. 13, no. 1, pp. 1-20, 2021. 